
FIT(PATOLOGI
Volume 13, Nomor 6, November 2017
I N DONESIA
Halaman 191-198
ISSN: 0215-7950
DOI: $10.14692 /$ jfi.13.6.191

\title{
Aplikasi Gelombang Mikro sebagai Pengendali Cendawan Patogen Terbawa Benih Kedelai
}

\author{
Micro wave Application to Control Seed-borne Fungal Pathogens of \\ Soybean
}

\author{
Raden Sujayadi, Supyani*, Edi Purwanto \\ Universitas Sebelas Maret, Surakarta 57126
}

\begin{abstract}
ABSTRAK
Salah satu kendala yang dihadapi dalam penyediaan benih kedelai (Glycine max) bermutu ialah infeksi cendawan patogen terbawa benih. Perlakuan gelombang mikro merupakan salah satu alternatif metode pengendalian cendawan terbawa benih yang cukup efektif sehingga perlu dikembangkan. Penelitian ini terdiri atas dua tahap. Tahap ke-1 bertujuan menetapkan kadar air benih kedelai yang baik untuk memertahankan mutu fisiologi benih menggunakan durasi gelombang mikro. Tahap ke-2 bertujuan menentukan durasi perlakuan gelombang mikro yang paling efektif mengurangi tingkat infeksi cendawan patogen terbawa benih menggunakan kadar air terbaik dari hasil percobaan tahap ke-1. Hasil penelitian menunjukkan bahwa kadar air $9.20 \%$ paling baik memertahankan mutu fisiologi benih setelah perlakuan gelombang mikro. Perlakuan gelombang mikro dengan durasi 60 detik mengendalikan Aspergillus flavus dengan efektif, sedangkan durasi 80 detik mengendalikan Fusarium sp., Curvularia sp., dan A. niger.
\end{abstract}

Kata kunci: Glycine max, kadar air benih, mutu fisiologi, tingkat infeksi

\begin{abstract}
One of the obstacles in providing high quality soybean (Glycine max) seed is the infection of seedborne fungal pathogens. Micro wave treatment is one of the alternative methods to control the seedborne pathogens effectively but it needs to be further developed. This research consisted of two stages. The first stage was aimed to determine the best soybean seed moisture content in maintaining seed physiological quality after exposing to micro wave. The second stage was aimed to determine the most effective duration of micro wave exposure to reduce the rate of infection of seed-borne fungal pathogens using the best moisture content resulted from the first stage. The experiment on seed moisture indicated that $9.20 \%$ was the best seed moisture content in maintaining the physiological quality when the seed was exposed to micro wave. Furthermore, micro wave exposure of 60 seconds was able to control Aspergillus flavus, while the exposure of 80 seconds was able to control Fusarium sp., Curvularia sp., and $A$. niger.
\end{abstract}

Key words: Glycine max, infection rate, physiological quality, seed moisture content

\footnotetext{
*Alamat penulis korespondensi: Program Studi Agroteknologi, Fakultas Pertanian, Universitas Sebelas Maret. Jalan Ir. Sutami No. 36-A, Kentingan, Surakarta 57126.

Tel: 0271-637457, Surel: supyani_id@yahoo.com.
} 


\section{PENDAHULUAN}

Kedelai merupakan sumber protein nabati yang penting dan murah. Sebanyak $67.28 \%$ (1.96 juta ton) kebutuhan nasional kedelai dipenuhi melalui impor (Pusdatin 2015). Salah satu faktor penyebabnya ialah produktivitas kedelai nasional yang rendah, yakni 1.57 ton ha $^{-1}$ pada tahun 2015 (BPS 2016).

Benih bermutu dan bersertifikat merupakan salah satu komponen utama untuk meningkatkan produksi kedelai. Salah satu aspek mutu benih ialah mutu patologi yang tinggi, artinya benih bebas dari infeksi patogen terbawa benih, baik cendawan, bakteri, virus, dan nematoda (Ilyas 2012).

Cendawan patogen terbawa benih dapat berada di permukaan, di dalam jaringan atau tercampur bebas bersama benih. Sumber inokulum cendawan berasal dari lapangan, kontaminasi saat panen, pengolahan, pengemasan, penyimpanan atau selama pendistribusian benih (Agarwal dan Sinclair 1996). Mathur dan Kongsdal (2003) melaporkan bahwa cendawan patogen yang terbawa benih kedelai diantaranya, yaitu Cercospora kikuchii, C. sojina, dan Fusarium spp. Menurut Ahmed et al.(2016), cendawan yang ditemukan pada benih kedelai antara lain Aspergillus spp., Curvularia spp., Fusarium spp., Penicillium spp., dan Phomopsis spp. Sedangkan jenis cendawan pada hasil penelitian Rao et al. (2015), antara lain M. phaseolina, C. dematium, Aspergillus flavus, A. niger, Rhizopus sp., Curvularia sp., Alternaria, Cladosporium, dan Fusarium sp.

Salah satu alternatif pengendalian cendawan patogen terbawa benih ialah perlakuan gelombang mikro, yang telah diujikan pada beberapa komoditas, antara lain kedelai (Reddy et al. 1995), aster cina (Han 2010), kacang buncis (Friesen et al. 2014), barley (Iuliana et al. 2013), dan cabai (Najah et al. 2016). Friesen et al. (2014) melaporkan paparan gelombang mikro kurang dari 50 detik dapat menurunkan tingkat infeksi patogen Colletotrichum lindemuthianum $(0.14 \%$ per detikpaparan), namuntetapmenjagapenurunan daya berkecambah sebesar $<10 \%$. Sementara
Reddy et al. (1995) menyatakan, semakin lama durasi perlakuan gelombang mikro pada benih kedelai yang diinokulasi buatan dengan patogen Diaphorte phaseolorum, tingkat infeksi patogen semakin menurun, serta diikuti dengan penurunan daya berkecambah dan vigor benih. Penelitian lain yang dilakukan oleh Motallebi (2016) terhadap benih kanola, kedelai dan kesumba yang diinokulasi buatan dengan $A$. niger menunjukkan bahwa semakin tinggi daya gelombang mikro, menyebabkan viabilitas benih dan tingkat infeksi patogen A. niger semakin menurun. Pada penelitian sebelumnya, kadar air benih yang digunakan jauh lebih tinggi dari persyaratan kadar air maksimum benih kedelai bersertifikat (11\%), selain itu cendawan patogen yang digunakan untuk inokulasi buatan hanya satu spesies.

Penelitian ini bertujuan untuk menentukan durasi perlakuan gelombang mikro dan kadar air yang paling efektif mengendalikan cendawan patogen terbawa benih kedelai, namun tetap dapat mempertahankan mutu fisiologis benih.

\section{BAHAN DAN METODE}

Alat yang digunakan antara lain oven micro wave komersial (LG, model MH6042D, $220 \mathrm{~V}-50 \mathrm{~Hz}, 2,450 \mathrm{MHz}, 450 \mathrm{~W})$, termometer, germinator cabinet tipe IPB $732 \mathrm{~A} / \mathrm{B}$, oven listrik (Memmert), cawan porselen, saringan 40 mesh, lemari pendingin (Kirsch), mikroskop stereo dan majemuk, serta alat penunjang lainnya. Benih kedelai yang digunakan adalah varietas Grobogan dari Kabupaten Grobogan, Jawa Tengah, dipanen bulan Oktober 2016. Penelitian terdiri atas dua tahap.

\section{Tahap I. Penentuan Kadar Air Benih dengan Mutu Fisiologis Terbaik Setelah Perlakuan Gelombang Mikro}

Tahap I bertujuan menetapkan kadar air benih kedelai yang paling baik mempertahankan mutu fisiologis benih setelah perlakuan gelombang mikro. Kadar air benih kedelai ditetapkan menjadi tiga taraf perlakuan, yaitu kadar air rendah $(9.20 \%)$, sedang $(11.25 \%)$, dan tinggi (13.73\%), yang 
dihitung menggunakan angka bobot benih awal dan bobot benih akhir yang ekuivalen dengan kadar air (KA) benih yang diinginkan dengan rumus berikut (ISTA 2014):

$\begin{aligned} & \text { Bobot benih } \\ & \text { yang diinginkan }\end{aligned}=\frac{100-\text { KA awal }}{100-\text { KA akhir }} \times \begin{gathered}\text { bobot awal } \\ \text { benih }\end{gathered}$

Bobot benih diturunkan dengan cara benih dijemur di bawah sinar matahari pada pukul 07.00-10.00 pagi pada wadah plastik dengan suhu maksimal $40{ }^{\circ} \mathrm{C}$, selama 2-4 hari sampai diperoleh bobot benih yang ekuivalen dengan tiga taraf kadar air yang diinginkan. Kadar air maksimum untuk benih kedelai berdasarkan standar pengujian laboratorium ialah sebesar 11\% (Kepmentan 2015).

Penetapan kadar air benih kedelai menggunakan metode oven suhu konstan tinggi (Kepmentan 2015). Sebanyak $10 \mathrm{~g}$ benih kedelai digerus menggunakan penggiling, disaring menggunakan saringan 40 mesh hingga diperoleh sebanyak 4.5-5 g butiran kasar, selanjutnya dimasukkan ke dalam cawan porselen untuk ditimbang beserta tutupnya. Cawan beserta tutupnya yang berisi butiran kasar dimasukkan ke dalam oven listrik dengan suhu konstan tinggi $130 \pm 2{ }^{\circ} \mathrm{C}$ selama 1 jam. Setelah itu, cawan didinginkan dalam desikator selama 30 menit dan ditimbang berat kering benih beserta cawan dan tutupnya yang dihitung dengan rumus berikut:

$$
\mathrm{KA}=\frac{\mathrm{M} 2-\mathrm{M} 3}{\mathrm{M} 2-\mathrm{M} 1} \times 100 \% \text {, dengan }
$$

KA, kadar air (\%); M1, berat cawan kosong; M2, berat awal (benih dan cawan sebelum dipanaskan dalam oven); M3, berat akhir (benih dan cawan setelah dipanaskan dalam oven).

Benih selanjutnya diberi perlakuan gelombang mikro menggunakan oven gelombang mikro frekuensi $2.450 \mathrm{MHz} /$ daya 450 W (Aladjadjiyan 2010). Dimasukkan pula beaker glass berisi air sebanyak $200 \mathrm{~mL}$ untuk mencegah kerusakan benih (Tylkowska et al. 2010). Durasi perlakuan gelombang mikro ialah 0, 20, 40, 60, 80, 100 detik. Benih selanjutnya diuji mutu fisiologisnya menggunakan metode uji antar kertas digulung (Kepmentan 2015). Sebanyak 400 butir benih kedelai untuk setiap perlakuan
(4 ulangan, masing-masing ulangan 100 butir) ditanam pada kertas buram yang telah dilembapkan dengan air steril, lalu digulung dan ditempatkan dalam germinator cabinet tipe IPB 73 2A/B pada suhu kamar.

Parameter mutu fisiologis yang diamati ialah viabilitas dan vigor benih. Viabilitas dengan tolok ukur daya berkecambah (DB) dan potensi tumbuh maksimum (PTM) dihitung menggunakan rumus berikut (ISTA 2014):

$\mathrm{DB}=\frac{\sum \mathrm{KN} \mathrm{I}+\sum \mathrm{KN} \mathrm{II}}{\sum \text { benih yang ditanam }} \times 100 \%$

PTM $=\frac{\sum \text { benih yang tumbuh }}{\sum \text { benih yang ditanam }} \times 100 \%$, dengan

DB, daya berkecambah; $\Sigma$ KN I, jumlah kecambah normal pada 5 hari setelah tanam (HST); $\Sigma$ KN II, jumlah kecambah normal pada 8 HST; dan PTM, potensi tumbuh maksimum.

Parameter vigor benih diamati dengan tolok ukur indeks vigor (IV) dan kecepatan tumbuh (KCT). Pengamatan KCT dilakukan setiap hari sampai hari ke-8. Perhitungan IV dan KCT menggunakan rumus berikut.

$$
\begin{gathered}
\mathrm{IV}=\frac{\sum \mathrm{KN} \mathrm{I}}{\sum \text { benih yang ditanam }} \times 100 \% \\
\operatorname{KCT}\left(\% \frac{\mathrm{KN}}{\text { etmal }}\right)=\sum_{0}^{\mathrm{tn}} \frac{\mathrm{N}}{\mathrm{t}} \text {, dengan }
\end{gathered}
$$

IV, indeks vigor; $\Sigma \mathrm{KN}$ I, jumlah kecambah normal pada 5 HST; KCT, kecepatan tumbuh; $\mathrm{N}$, persentase kecambah normal setiap waktu pengamatan; dan tn, waktu akhir pengamatan (hari ke-8).

Percobaan ini disusun dalam rancangan acak lengkap (RAL) faktorial. Setiap perlakuan diulang sebanyak 4 kali. Kadar air benih yang paling baik dalam memertahankan mutu fisiologisnya setelah diberi perlakuan gelombang mikro digunakan sebagai kadar air benih acuan untuk tahap II.

\section{Tahap II. Pengaruh Durasi Perlakuan Gelombang Mikro terhadap Tingkat Infeksi Cendawan Patogen Terbawa Benih Kedelai}

Tahap ini bertujuan menentukan durasi perlakuan gelombang mikro yang paling baik 
menurunkan tingkat infeksi cendawan terbawa benih. Sebanyak 200 butir benih kedelai (4 ulangan, masing-masing sebanyak 50 butir) diberi perlakuan gelombang mikro selama $0,20,40,60,80,100$ detik. Selanjutnya dilakukan uji kesehatan benih menggunakan metode blotter test (Mathur dan Kongsdal 2003). Benih disterilisasi permukaan dengan cara direndam dalam larutan $\mathrm{NaOCl} 1 \%$ selama 1 menit, kemudian dibilas air steril 3 kali, dikeringanginkan di atas kertas saring steril pada kondisi aseptik. Selanjutnya, sebanyak 25 butir benih ditanam pada cawan petri berisi 3 lembar kertas saring yang telah dilembapkan dengan air steril. Cawan petri tersebut ditutup dan disegel plastik wrap, lalu diinkubasi dalam inkubator pada suhu $20-25^{\circ} \mathrm{C}$ selama 24 jam dengan penyinaran near ultra violet (NUV) 12 jam terang dan 12 jam gelap secara bergantian. Benih kemudian diletakkan pada lemari pendingin pada suhu $-20{ }^{\circ} \mathrm{C}$ selama 24 jam dan diinkubasi kembali dalam inkubator pada suhu $20-25{ }^{\circ} \mathrm{C}$ selama 5 hari dengan penyinaran NUV selama 12 jam terang dan 12 jam gelap secara bergantian. Pada hari ke-8 setelah tanam dilakukan pengamatan menggunakan mikroskop stereo dan majemuk untuk deteksi dan identifikasi cendawan yang tumbuh pada benih kedelai serta dihitung jumlah benih yang terinfeksi masing-masing cendawan.

Identifikasi spesies cendawan terbawa benih berdasarkan tipe pertumbuhan dan morfologi struktur cendawan seperti hifa, tubuh buah, spora, konidium dan koloni menggunakan acuan yang dibuat oleh Mathur dan Kongsdal (2003) dan Mathur dan Manandhar (2003).

Tingkat infeksi cendawan pada benih dihitung menggunakan rumus berikut:

Tingkat infeksi $=\frac{\sum \text { benih terinfeksi }}{\sum \text { benih yang ditanam }} \times 100 \%$

Rancangan yang digunakan pada percobaan ini RAL satu faktor, yaitu durasi perlakuan gelombang mikro dengan 4 ulangan untuk setiap perlakuan.

\section{Analisis Data}

Data dianalisis menggunakan uji $\mathrm{F}$ untuk mengetahui pengaruh tiap perlakuan. Apabila hasil analisis menunjukkan adanya pengaruh nyata dari perlakuan, akan diuji lanjut dengan DMRT pada $\alpha 5 \%$.

\section{HASIL}

\section{Kadar Air Benih Kedelai dengan Mutu Fisiologis Terbaik Setelah Perlakuan Gelombang Mikro}

Hasil analisis ragam interaksi pengaruh kadarairdan durasiperlakuangelombang mikro menunjukkan pengaruh nyata terhadap mutu fisiologis benih kedelai. Semakin lama durasi gelombang mikro, maka daya berkecambah benih semakin menurun. Pada kadar air yang rendah, benih mampu berkecambah lebih baik apabila durasi perlakuan gelombang mikro meningkat (Tabel 1). Durasi paparan 100 detik merupakan perlakuan gelombang mikro yang mematikan sehingga menurunkan daya berkecambah (DB) dan potensi tumbuh maksimum (PTM) benih dengan kadar air rendah (9.20\%), sedangkan pada kadar air benih sedang $(11.25 \%)$ dan kadar air benih tinggi (13.73\%) durasi perlakuan gelombang mikro yang mematikan terjadi pada 80 detik dan 60 detik (Tabel 1). Pengaruh durasi perlakuan gelombang mikro tersebut, terjadi pula terhadap vigor benih kedelai, yaitu indeks vigor (IV) dan kecepatan tumbuh benih kedelai (Tabel 2).

\section{Pengaruh Durasi Perlakuan Gelombang Mikro terhadap Tingkat Infeksi Cendawan Patogen Terbawa Benih Kedelai}

Hasil uji kesehatan benih dengan blotter test menunjukkan sebanyak 6 spesies cendawan patogen terbawa benih kedelai terdeteksi dan teridentifikasi, yaitu Fusarium sp., Cladosporium sp., Curvularia sp., Cercospora sp., A. flavus dan A. niger. Dari semua cendawan yang ditemukan Fusarium sp. dan $A$. flavus merupakan cendawan terbawa benih kedelai dengan tingkat infeksi 
Tabel 1 Interaksi kadar air benih dan durasi perlakuan gelombang mikro terhadap viabilitas benih kedelai

\begin{tabular}{ccccccc}
\hline \multirow{2}{*}{$\begin{array}{c}\text { Kadar air } \\
(\%)\end{array}$} & 0 & 20 & 40 & 60 & 80 & 100 \\
\cline { 2 - 6 } & \multicolumn{7}{c}{ Daya berkecambah (\%) } \\
9.20 & $86.3 \mathrm{ab}$ & $89.0 \mathrm{a}$ & $89.5 \mathrm{a}$ & $76.5 \mathrm{c}$ & $78.5 \mathrm{bc}$ & $66.3 \mathrm{~d}$ \\
11.25 & $92.3 \mathrm{a}$ & $87.3 \mathrm{ab}$ & $91.8 \mathrm{a}$ & $88.3 \mathrm{ab}$ & $67.5 \mathrm{~d}$ & $20.0 \mathrm{f}$ \\
13.73 & $93.0 \mathrm{a}$ & $87.8 \mathrm{ab}$ & $87.3 \mathrm{ab}$ & $65.8 \mathrm{~d}$ & $34.3 \mathrm{e}$ & $11.5 \mathrm{f}$ \\
& & Potensi tumbuh maksimum (\%) & & \\
9.20 & $97.5 \mathrm{a}$ & $96.3 \mathrm{a}$ & $98.0 \mathrm{a}$ & $91.5 \mathrm{ab}$ & $96.0 \mathrm{a}$ & $88.8 \mathrm{bc}$ \\
11.25 & $98.8 \mathrm{a}$ & $99.0 \mathrm{a}$ & $98.8 \mathrm{a}$ & $97.3 \mathrm{a}$ & $80.5 \mathrm{~d}$ & $29.0 \mathrm{f}$ \\
13.73 & $98.0 \mathrm{a}$ & $97.8 \mathrm{a}$ & $98.8 \mathrm{a}$ & $82.0 \mathrm{~cd}$ & $50.0 \mathrm{e}$ & $20.8 \mathrm{~g}$ \\
\hline
\end{tabular}

Angka dalam kolom dan baris pada masing-masing tolok ukur yang diikuti huruf yang sama menunjukkan tidak berbeda nyata menurut uji Duncan pada $\alpha$ 5\%.

Tabel 2 Interaksi kadar air benih dan durasi perlakuan pemanasan gelombang mikro terhadap vigor benih kedelai

\begin{tabular}{lcccccc}
\hline \multirow{2}{*}{$\begin{array}{c}\text { Kadar air } \\
(\%)\end{array}$} & 0 & \multicolumn{6}{c}{ Durasi perlakuan gelombang mikro (detik) } \\
\cline { 2 - 6 } & \multicolumn{7}{c}{ Indeks vigor (\%) } \\
9.20 & $78.8 \mathrm{abc}$ & $81.5 \mathrm{ab}$ & $84.0 \mathrm{a}$ & $69.5 \mathrm{~d}$ & $73.0 \mathrm{bc}$ & $59.5 \mathrm{e}$ \\
11.25 & $85.8 \mathrm{a}$ & $80.8 \mathrm{ab}$ & $85.0 \mathrm{a}$ & $79.0 \mathrm{abc}$ & $59.3 \mathrm{e}$ & $19.0 \mathrm{~g}$ \\
13.73 & $88.3 \mathrm{a}$ & $82.5 \mathrm{ab}$ & $83.5 \mathrm{a}$ & $61.5 \mathrm{de}$ & $33.3 \mathrm{f}$ & $11.3 \mathrm{~g}$ \\
& \multicolumn{7}{c}{ Kecepatan tumbuh $\left(\%\right.$ etmal $\left.^{-1}\right)$} \\
9.20 & $20.4 \mathrm{ab}$ & $20.7 \mathrm{ab}$ & $21.2 \mathrm{a}$ & $17.9 \mathrm{c}$ & $18.4 \mathrm{bc}$ & $15.6 \mathrm{~d}$ \\
11.25 & $21.6 \mathrm{a}$ & $20.1 \mathrm{abc}$ & $21.9 \mathrm{a}$ & $20.3 \mathrm{ab}$ & $15.4 \mathrm{~d}$ & $4.5 \mathrm{f}$ \\
13.73 & $22.2 \mathrm{a}$ & $21.0 \mathrm{a}$ & $21.2 \mathrm{a}$ & $15.7 \mathrm{~d}$ & $8.3 \mathrm{e}$ & $2.7 \mathrm{f}$ \\
\hline
\end{tabular}

Angka dalam kolom dan baris pada masing-masing tolok ukur diikuti huruf yang sama menunjukkan tidak berbeda nyata menurut uji Duncan pada $\alpha 5 \%$.

tinggi, yaitu berturut-turut sebanyak $25.50 \%$ dan $17.00 \%$ (Tabel 3).

Hasil analisis ragam menunjukkan durasi perlakuan gelombang mikro memengaruhi tingkat infeksi cendawan terbawa benih kedelai, kecuali Cladosporium sp. Semakin lama perlakuan gelombang mikro, tingkat infeksi cendawan pada benih kedelai semakin menurun. Pada perlakuan gelombang mikro dengan durasi 100 detik infeksi cendawan terbawa benih dapat dihilangkan, kecuali $A$. flavus yang masih mampu menginfeksi benih kedelai sebesar $8.50 \%$ (Tabel 3).

\section{PEMBAHASAN}

Hasil penelitian menunjukkan bahwa kadar air dan durasi perlakuan gelombang mikro berpengaruh nyata terhadap mutu fisilogis benih kedelai. Mutu fisiologis benih kedelai akan cepat menurun pada perlakuan gelombang mikro apabila kadar air benih kedelai tinggi. Pada benih kedelai dengan kadar air rendah (9.20\%), mutu fisiologis benih mulai menurun bila benih diberi perlakuan gelombang mikro selama 60 detik. Sebaliknya pada kadar air sedang dan tinggi ( $11.25 \%$ dan $13.73 \%$ ), mutu fisiologis benih kedelai mulai menurun pada perlakuan gelombang mikro selama 20 detik. Hal tersebut sesuai dengan hasil penelitian Najah et al. (2016) yang menunjukkan benih cabai pada kadar air rendah $(4.31 \%)$ dapat memertahankan viabilitas benih walaupun terpapar gelombang mikro selama 40 detik, sedangkan viabilitas benih berkadar air sedang $(6.33 \%)$ dan tinggi $(8.25 \%)$ mulai menurun saat perlakuan gelombang mikro selama 20 detik. Knox et al. (2013) menyatakan bahwa 
Tabel 3 Pengaruh durasi perlakuan gelombang mikro terhadap tingkat infeksi cendawan patogen terbawa benih kedelai $(\%)$

\begin{tabular}{lrccccc}
\hline \multirow{2}{*}{ Cendawan } & \multicolumn{7}{c}{ Durasi perlakuan gelombang mikro (detik) } \\
\cline { 2 - 7 } & 0 & 20 & 40 & 60 & 80 & 100 \\
\hline Aspergillus flavus & $25.50 \mathrm{a}$ & $23.00 \mathrm{ab}$ & $14.50 \mathrm{bc}$ & $8.50 \mathrm{c}$ & $14.50 \mathrm{bc}$ & $8.50 \mathrm{c}$ \\
Aspergillus niger & $4.00 \mathrm{a}$ & $1.50 \mathrm{~b}$ & $0.50 \mathrm{~b}$ & $1.00 \mathrm{~b}$ & $0.00 \mathrm{~b}$ & $0.00 \mathrm{~b}$ \\
Fusarium sp. & $17.00 \mathrm{a}$ & $6.50 \mathrm{~b}$ & $5.00 \mathrm{~b}$ & $7.00 \mathrm{~b}$ & $1.00 \mathrm{c}$ & $0.00 \mathrm{c}$ \\
Cercospora $\mathrm{sp}$. & $1.50 \mathrm{a}$ & $0.00 \mathrm{a}$ & $2.00 \mathrm{a}$ & $0.50 \mathrm{a}$ & $0.00 \mathrm{a}$ & $0.00 \mathrm{a}$ \\
Cladosporium sp. & $0.50 \mathrm{a}$ & $0.50 \mathrm{a}$ & $0.50 \mathrm{a}$ & $0.00 \mathrm{a}$ & $1.00 \mathrm{a}$ & $0.00 \mathrm{a}$ \\
Curvularia sp. & $2.50 \mathrm{a}$ & $2.00 \mathrm{ab}$ & $1.00 \mathrm{ab}$ & $1.00 \mathrm{ab}$ & $0.00 \mathrm{~b}$ & $0.00 \mathrm{~b}$ \\
\hline Ang
\end{tabular}

Angka dalam baris yang diikuti huruf yang sama menunjukkan tidak berbeda nyata menurut uji Duncan pada $\alpha .5 \%$.

daya berkecambah benih gandum berkadar air rendah (3\% dan $10 \%)$ tetap tinggi setelah perlakuan gelombang mikro selama 15 detik, sedangkan daya berkecambah benih gandum berkadar air tinggi $(20,25$, dan $40 \%)$ menurun drastis.

Kadar air benih merupakan faktor penting yang menentukan kemampuan benih memertahankan mutu fisiologisnya setelah perlakuan gelombang mikro. Gaurilcikiene et al. (2013) menjelaskan pada perlakuan gelombang mikro, daya berkecambah dan vigor benih semakin menurun bila kadar air awal benih meningkat. Sementara Saltiel dan Datta (1999) menyatakan penyerapan gelombang mikro suatu bahan meningkat seiring dengan semakin tinggi kadar air dari bahan tersebut.

Penurunan mutu fisiologis yang cepat pada benih kedelai dengan kadar air tinggi setelah terpapar gelombang mikro, diduga karena kenaikan suhu benih yang lebih cepat. Hasil penelitian More etal. (1992) pada benih sorgum menunjukkan pada perlakuan gelombang mikro yang sama, suhu benih tertinggi dicapai pada benih dengan kadar air tinggi (16\%). Bouraoui et al. (1993) menyatakan pemanasan dielektrik, yaitu pemanasan menggunakan radiasi elektromagnetik frekuensi tinggi, dapat memanaskan bahan dieletrik yang mengandung molekul-molekul bermuatan positif dan negatif. Molekul-molekul tersebut akan bergerak dan saling bertumbukan ketika diberi gelombang elektromagnetik yang berasal dari oven gelombang mikro sehingga menghasilkan panas. Menurut Mujumdar (2003), pengaruh panas dari perlakuan gelombang mikro terhadap suatu bahan ditentukan dari kemampuan bahan tersebut untuk menyerap gelombang mikro, disebut juga loss factor. Benih yang mempunyai kadar air tinggi memiliki angka loss factor yang tinggi sehingga benih tersebut menyerap gelombang elektromagnetik lebih banyak dan meningkatkan suhu benih dengan cepat.

Berdasarkan hasil blotter test, perlakuan gelombang mikro mampu menekan tingkat infeksi cendawan patogen terbawa benih kedelai, yaitu Fusarium sp., Curvularia sp., dan $A$. niger pada perlakuan gelombang mikro selama 80 detik dengan tingkat penurunan berturut-turut sebesar $94.12 \%, 100 \%$, dan $100 \%$ dibandingkan kontrol, sedangkan tingkat infeksi $A$. flavus dapat ditekan pada perlakuan gelombang mikro selama 60 detik dengan tingkat penurunan mencapai $43.14 \%$ dibandingkan kontrol.

Pengamatan Reddy et al. (1998) pada benih gandum menunjukkan tingkat infeksi cendawan $F$. graminearum menurun apabila perlakuan pemanasan gelombang mikro meningkat dan diikuti dengan penurunan daya berkecambah dan vigor benih. Han (2010) melaporkan perlakuan pemanasan gelombang mikro pada benih aster cina dalam air selama 60 detik dan 120 detik pada kondisi kering secara nyata menurunkan tingkat infeksi cendawan A. alternata. Penelitian Arengka (2014) menunjukkan perlakuan gelombang mikro selama 30 detik dapat mengurangi tingkat infeksi $F$. subglitans dan A. niger berturutturut sebanyak $75.0 \%$ dan $54.80 \%$ pada benih jagung manis dengan kadar air rendah (12.31\%). Sementara Najah et al. (2016) 
melaporkan perlakuan gelombang mikro selama 40 detik pada benih cabai dengan kadar air rendah efektif menurunkan tingkat infeksi C. acutatum dengan tingkat efikasi mencapai $64.3 \%$.

Perlakuan gelombang mikro dapat digunakan sebagai alternatif dalam mengendalikan cendawan terbawa benih kedelai. Kadar air benih rendah $(9.20 \%)$ paling baik memertahankan mutu fisiologis benih kedelai setelah diberi perlakuan gelombang mikro. Durasi perlakuan gelombang mikro selama 80 detik paling efektif mengendalikan Fusarium sp., Curvularia sp., dan $A$. niger, sedangkan perlakuan 60 detik dapat menurunkan tingkat infeksi $A$. flavus.

\section{UCAPAN TERIMA KASIH}

Penulis menyampaikan terima kasih kepada Badan Penyuluhan dan Pengembangan SDM Pertanian, Kementrian Pertanian yang telah memberikan beasiswa pendidikan dan Balai Besar Pengembangan Pengujian Mutu Benih Tanaman Pangan dan Hortikultura (BB-PPMBTPH) atas segala dukungan dalam pelaksanaan penelitian.

\section{DAFTAR PUSTAKA}

Agarwal VK, Sinclair JB. 1996. Principles of Seed Pathology. Ed ke-2. Florida (US):CRC Press.

Ahmed O, Balogun OS, Fawole OB, Fabiyi OA, Hussein AT, Kassoum KO. 2016. Seed-borne fungi of soybeans (Glycine $\max$ [1.] Merr) in the guinea savannah agroecology of nigeria. J Agric Sci. 61(1): 57-68. DOI: http://dx.doi.org/10.2298/ JAS1601057A.

Aladjadjiyan A. 2010. Effect of microwave irradiation on seeds of lentils (Lens culinaris, Med.). Rom J Biophys. 20(3):213-221.

Arengka D. 2014. Pemanfaatan gelombang mikro untuk mengendalikan patogen terbawa benih jagung manis (Zea mays saccharata Sturt.) [tesis]. Bogor (ID): Institut Pertanian Bogor.
Bouraoui M, Richard P, Fichtali J. 1993. A review of moisture content determination in foods using microwave oven drying. Food Res Int. 26: 49-57. DOI: http://dx.doi. org/10.1016/0963-9969(93)90105-R.

[BPS] Badan Pusat Statistik. 2016. Produktivitas kedelai menurut provinsi (kuintal/ha), 1993-2015. http://www.bps. go.id [diakses 3 Sep 2016].

Friesen AP, Conner RL, Robinson DE, Barton WR, Gillard CL. 2014. Effect of microwave radiation on dry bean seed infected with Colletotrichum lindemuthianum with and without the use of chemical seed treatment. Can J Plant Sci. 94(8):1373-1384. DOI: http://dx.doi.org/10.4141/cjps-2014-035.

Gaurilcikiene I, Ramanauskiene J, Dagys M,Simniskis R, Dabkevicius Z, Suproniene S. 2013. The effect of strong micro wave electric field radiation on: (2) wheat (Triticum aestivum L.) seed germination and sanitation. Zemdirb Agric. 100(2):185-190. DOI: http://dx.doi. org/10.13080/z-a.2013.100.024.

Han F. 2010. The effect of microwave treatment on germination, vigour and health of china aster (Callistephus chinensis Nees.) seeds. J Agric Sci. 2(4):201-210. DOI: http:// dx.doi.org/10.5539/jas.v2n4p201.

Ilyas S. 2012. Ilmu dan Teknologi Benih (Teori dan Hasil-hasil Penelitian). Bogor (ID): IPB Press.

Iuliana C, Giancarla V, Sorina R. 2013. The effect of microwave irradiation on the germination of barley seeds (Hordeum vulgare L.). Di dalam: $48^{\text {th }}$ Croatian $\& 8^{\text {th }}$ International Symposium on Agriculture; 2013 Feb 17-22; Dubrovnik (HR): Josip Juraj Strossmayer University of Osijek. hlm 254-258.

[ISTA] International Seed Testing Association. 2014. International Rules for Seed Testing. 2014 edition. Zürich (CH): ISTA.

[Kepmentan] Keputusan Menteri Pertanian RI. 2015. Keputusan Menteri Pertanian RI No. 635/HK.150/C/07/2015 tentang Pedoman Teknis Pengambilan Contoh Benih dan Pengujian/Analisis Mutu Benih Tanaman Pangan. 
Knox OGG, McHugh MJ, Fountaine JM, Havis ND. 2013. Effects of microwaves on fungal pathogens of wheat seed. Cropping Systems Research Group. Scotland's Rural College (SAC). United Kingdom. Crop Protection. 50:12-16. DOI: http://dx.doi. org/10.1016/j.cropro.2013.03.009.

Mathur SB, Kongsdal O. 2003. Common Laboratory Seed Health Testing Methods for Detecting Fungi. Ed ke-1. Basserdorf $(\mathrm{CH})$ : ISTA.

Mathur SB, Manandhar HK. 2003. Fungi in Seeds. Ed ke-1. Copenhagen (DK): DGISP.

More HG, Magan N, Stenning BC. 1992. Effect of microwave heating on quality and mycoflora of sorghum grain. J Stored Prod Res. 28(4): 251-256. DOI: http://dx.doi. org/10.1016/0022-474X(92)90005-B.

Motallebi A. 2016. Effect of microwave radiation on seed viability, survival of Aspergillus niger van tieghem and oil quality of oilseeds crops canola, soybean and safflower. Acta Agric Slov. 107(1):7380. DOI: http://dx.doi.org/10.14720/ aas.2016.107.1.08.

Mujumdar AS. 2003. Drying Technology in Agriculture and Food Sciences. Enfield(US): Science Publishers, Inc.

Najah LN, Suhartanto MR, Widodo. 2016. Pengendalian Colletotrichum spp. terbawa benih cabai dengan paparan gelombang mikro. J Fitopatol Indones. 12(4):115123. DOI: http://dx.doi.org/10.14692/ jfi.12.4.115.
[Pusdatin] Pusat Data dan Sistem Informasi Pertanian Kementerian Pertanian. 2015. Outlook komoditas pertanian subsektor tanaman pangan: kedelai. http://epublikasi. setjen.pertanian.go.id/arsip-outlook/81outlook-tanaman-pangan [diakses 5 Sep 2016].

Rao TV, Rajeswari B, Keshavulu K, Varma VS. 2015. Studies on seedborne fungi of soybean. SSRG J Agric Env Sci. 2(1):1624.

Reddy MVB, Kushalappa AC, Raghavan GSV, Stephenson MMP. 1995. Use of microwave energy for the eradication of seedborne Diaporthe phaseolorum in soybean and its effect on seed quality. J Microw Power Electromagn Energy. 30(4):199-204.

Reddy MVB, Raghavan GSV, Kushalappa AC, Paulitz TC. 1998. Effect of microwave treatment on quality of wheat seeds infected with Fusarium graminearum. J agric Engng Res. 71:113-117. DOI: http:// dx.doi.org/10.1006/jaer.1998.0305.

Saltiel C, Datta AK. 1999. Heat and mass transfer in microwave processing. Adv heat transfer. 33:1-94. DOI: http://dx.doi. org/10.1016/S0065-2717(08)70303-4. 